out that this is an optional feature of the subjective party, despite the explanation of the Plenum of the Supreme Court of Ukraine.

Key words: proceeds from crime, legalization (laundering) of incomes, counteraction to money laundering, predicate crime, terrorist financing.

УДК 343.985 .3

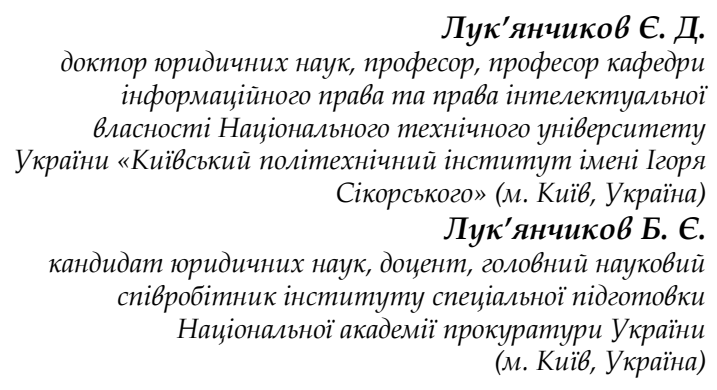

\title{
ФОРМУВАННЯ ІНСТИТУТУ НЕГЛАСНИХ СЛІДЧИХ (РОЗШУКОВИХ) ДІЙ
}

У статті проаналізовано нормативне регулювання інструментарію пізнавальної діяльності 3 розслідування кримінальних правопорушень. Розглянуто думки науковців щодо визначення слідчих дій і відмежування їх від інших процесуальних дій і засобів забезпечення кримінального провадження. Розкрито об'єктивні передумови закріплення в КПК України низки слідчих (розшукових) дій, відомості про факт та методи проведення яких не підлягають розголошенню.

Зроблено висновок про те, що запровадження інституту негласних слідчих (розшукових) дій $є$ закономірним результатом розвитку кримінального процесуального законодавства, головна мета якого полягає в забезпеченні прав та інтересів обох сторін кримінального провадження.

Ключові слова: злочин, засоби пізнавальної діяльності, слідчі (розшукові) дії, процесуальні дії, пошук, розшук, розшукова діяльність.

Постановка проблеми. Сучасний етап розвитку суспільства супроводжується суттєвими змінами в економіці, політищі, розвитку міжнародних відносин. Негативного впливу на ці процеси завдає злочинність, яка характеризується не тільки кількісними, а здебільшого якісними змінами. 3'являються нові види злочинів (у сфері високих технологій, розкрадання в бюджетній та фінансово-кредитній сферах), зростає корисливо-насильницька злочинність, дії злочинців стають усе більш жорстокими та зухвалими, підвищується професіоналізація, організованість і корумпованість злочинності, яка набуває транснаціонального характеру. На цьому тлі знижується, за різних обставин, активність законослухняних громадян у наданні правоохоронним органам інформації про злочини, яка стала їм відомою. 3 огляду на це зменшуються інформаційні можливості правоохоронних органів у своєчасному виявленні злочинів, встановленні всіх його обставин та осіб, причетних до цього. Суттєве зростання навантаження на правоохоронні органи та збільшення () Лук'янчиков С.Д.,

Лук'янчиков Б.С., 2019 
кількості злочинів, що залишаються нерозкритими, є об'єктивною передумовою подальших пошуків, розроблення й застосування нових пізнавальних засобів і прийомів роботи 3 джерелами інформації про обставини злочинів, які перебувають у провадженні слідчого.

Аналіз останніх досліджень i публікацій. Дослідженню засобів пізнавальної діяльності з розкриття та розслідування злочинів присвячені праці таких вітчизняних та зарубіжних науковців, як В.П. Бахін, Р.С. Бєлкін, А. Ф. Волобуєв, В. І. Галаган, В. Г. Гончаренко, А. Я. Дубинський, В. А. Журавель, О. Н. Колесніченко, В. О. Коновалова, О. М. Ларін, І. М. Лузгін, В. Г. Лукашевич, М. А. Погорецький, Д. Б. Сергєєва, В. В. Тіщенко, С. А. Шейфер, В. Ю. Шепітько, М. Є. Шумило та інші.

Швидке, повне та неупереджене розслідування злочинів є завданням кримінального провадження (ст. 2 КПК), забезпечуючись оптимальним використанням пізнавального інструментарію кримінально-процесуальної діяльності, - слідчих (розшукових) дій, що потребує їх поглибленого дослідження в умовах оновленого кримінального процесуального законодавства.

Формування цілей. Метою статті є з'ясування сутності негласних слідчих (розшукових) дій, визначення їх місця в системі засобів формування судових доказів, дослідження процесу їх становлення та нормативного закріплення на різних етапах формування законодавства, що регулює правові відносини у галузі кримінального провадження.

Виклад основного матеріалу. Поступовий рух України в напрямі євроінтеграції потребує від державних органів надійного забезпечення прав та законних інтересів громадян. Передусім йдеться про захист громадян від кримінальних правопорушень. Державні органи, на які покладено обов' язок своєчасного виявлення та розкриття злочинів, мають володіти надійними засобами отримання інформації про них. Оскільки така діяльність передбачає можливість втручання в права та інтереси громадян, вона має бути врегульована нормами закону. Саме цим пояснюється тривале опрацювання нового КПК України. Розробники здійснили спробу закріпити норми, що будуть забезпечувати права та свободи особи, яка підозрюється у вчиненні злочину. Без уваги не залишена й інша сторона - потерпілий, тобто особа, яка зазнала шкоди від злочину і потребує поновлення іï прав та законних інтересів. 3 огляду на сучасний характер злочинності, а також потребу своєчасного виявлення злочинів, що готуються, та розслідування вже вчинених, зумовив законодавця суттєво розширити засоби пізнавальної діяльності. Зокрема, до чинного КПК України внесено главу 21, яка регулює порядок проведення негласних слідчих (розшукових) дій.

Оцінюючи зміни, які відбулись у кримінальному процесуальному законодавстві України з прийняттям нового КПК, А. Солодков зазначає, що до нього імплементовано європейські стандарти в галузі захисту прав людини ..., про що можна з упевненістю констатувати, які багаторічною практикою застосування в європейських країнах довели свою ефективність [1, с. 55-56]. Певною мірою це стосується інституту слідчих (розшукових) дій, у якому збережено традиційні засоби отримання відомостей про обставини 
злочину в кримінальному провадженні та запроваджено нові засоби пізнавальної діяльності з розслідування - негласні (слідчі) розшукові дії.

Слідчі дії - один з усталених інститутів кримінального процесу. Вони складають частину процесуальних дій, які мають пошукову, пізнавальну спрямованість. Відсутність нормативного визначення поняття слідчих дій спонукала науковців до його опрацювання, що було сформульовано під час тривалих дискусій. Під слідчими діями пропонується розуміти передбачені кримінально-процесуальним законом дії, спрямовані на отримання (розшукування, збирання) або перевірку вже отриманих доказів у конкретному кримінальному провадженні. Вони є різновидом більш широкого за змістом поняття процесуальних дій, що проводять слідчий або особа, яка проводить дізнання (а у визначених законом випадках - прокурор i начальник слідчого підрозділу) на стадії досудового розслідування відповідно з визначеними процедурними вимогами, мають пізнавальну спрямованість, тобто завжди спрямовані на отримання, фіксацію або перевірку доказів [2, с. 215].

Всі інші дії слідчого в кримінальному провадженні, як слушно зауважує М. Погорецький, хоча іє процесуальними, оскільки здійснює їх уповноважений суб'єкт процесу у визначеній КПК України процесуальній формі, та спрямовані на досягнення мети вирішення завдань кримінального провадження, проте не мають значення слідчих (розшукових) дій [3, с. 49].

Піддаючи аналізу пізнавальний інструментарій 3 розслідування злочинів, не можна оминути те, що чинний КПК України, з одного боку, суттєво розширює засоби одержання інформації слідчим, а з іншого, наділяє його правом застосування пізнавальних прийомів і методів, що тривалий час були притаманними оперативним підрозділам. За своєю сутністю вони нагадують оперативно-розшукові заходи, що назвали слідчими (розшуковими) діями. На цій підставі окремі науковці вважають, що відбулося часткове злиття кримінально-процесуального та оперативнорозшукового законодавства [4, с. 107]. Натомість М. Шумило вказує на часткове об' єднання не законодавства, а поліційної (оперативно-розшукової) та процесуальної діяльності, що передбачає перевірку первинних даних про можливий злочин у сфері кримінального провадження під контролем кримінального процесуального закону з дотриманням його форм і гарантій [5, с. 228-229]. Таке твердження повною мірою не відповідає дійсності. Кожний із цих видів діяльності врегульований окремими законами. Кримінальне провадження здійснюють визначені в КПК учасники процесу й тільки кримінальними процесуальними засобами. Негласні слідчі (розшукові) дії не є будь-яким різновидом оперативно-розшукових заходів. Підстави, коло осіб, які наділені правом їх ініціювання, та порядок отримання дозволу на їх застосування визначені процесуальним законом. Слушно зазначає В. Шерудило, що негласні слідчі (розшукові) дії та оперативно-розшукові заходи, передбачені ст. 8 Закону України «Про оперативно-розшукову діяльність» не є тотожними за метою, завданнями, підставами, процесуальним значенням отриманих результатів, об'єктом, формами й методами відомчого контролю та прокурорського нагляду, 
використанням отриманих результатів, організаційною сутністю, змістом проваджуваних дій [6, с. 8].

Свого часу А. Дубинський звертав увагу на те, що зрощування цих двох функцій (видів діяльності) неприпустимо, оскільки воно може негативно позначитися на оцінці доказів, об'єктивності розслідування, формуванні висновків у кримінальній справі [7, с. 89]. У науковій і навчальній літературі радянського періоду, зазначає М. Шумило, загальновизнаною була позиція про те, що оперативно-розшукову і кримінально-процесуальну діяльність змішувати небезпечно [8, с. 24-29].

Зазначимо, що й на сьогодні розкриття злочинів забезпечується двома видами діяльності - кримінальної процесуальної та оперативно-розшукової, кожна 3 яких урегульована самостійними законами. Закріплення у відповідних нормах однакових методів та прийомів пізнання не треба розглядати як злиття цих видів діяльності. Інших методів отримання інформації як спостереження під час огляду, опитування особи, проведення дослідів не існує. Проте вони отримують нормативне закріплення залежно від виду діяльності, у якій їх застосовують. Зокрема, тривалий час для отримання інформації від людей використовують допит - під час проведення розслідування та опитування - у процесі оперативнорозшукової діяльності. Однак не натрапляли на висловлювання про те, що в КПК закріплено оперативно-розшуковий захід. Це стосується різних видів огляду, які успішно застосовують у кримінальній процесуальній та оперативно-розшуковій діяльності, але нормативне їх врегулювання відрізняється.

Не можна оминути увагою й те, що кримінальна процесуальна діяльність, зокрема застосування негласних методів отримання інформації під час розслідування, відбувається у суттєво змінених умовах, порівняно 3 регулюванням за КПК України 1960 року. Діяльність слідчого проходить під пильним процесуальним контролем прокурора, а застосування негласних засобів отримання інформації зазвичай відбувається тільки 3 дозволу слідчого судді апеляційного суду (ст. $247 \mathrm{KПК),} \mathrm{яким} \mathrm{є} \mathrm{голова} \mathrm{чи} \mathrm{за} \mathrm{його}$ визначенням інший суддя цього суду (п. 18 ч. 1 ст. 3 КПК). Такий порядок дозволу на застосування негласних засобів отримання інформації про обставини злочину створює додаткові гарантії захисту прав та інтересів особи, щодо якої такі заходи застосовують. Зауважимо, що гарантії забезпечення конституційних прав і свобод особи під час проведення негласних слідчих (розшукових) дій досліджувалися в науковій літературі [9, с. 251- 254].

Здійснюючи аналіз інституту засобів негласного отримання інформації про злочин, доходимо висновку, що не зовсім правильно твердити, що вони вперше запроваджені в КПК України 2012 року. 3 давніх часів на поліцію покладалося здійснення дізнання для встановлення особи, яка вчинила злочин. Проводилося воно через допит свідків, використання чуток, речових доказів. Таємні методи розкриття злочинів застосовували поодиноко [10, с. 7]. Зокрема, у ст. 254 Статуту кримінального судочинства зазначалось, що поліція під час проведення дізнання збирає необхідні відомості в спосіб 
проведення розшуку, словесного розпитування та негласного спостереження без проведення обшуків та виїмок у житлі. У цьому разі дізнання розглядають у ширшому розумінні, ніж кримінально-процесуальну діяльність. До нього відносять проведення розшуку, словесне розпитування та негласне спостереження. Відповідно до КПК України 1960 року поняття дізнання охоплювало тільки кримінальну процесуальну діяльність, а це є форма досудового розслідування. Подібний підхід до дізнання зберігається і в КПК України 2012 року. У формі дізнання здійснюється досудове розслідування кримінальних проступків (ст. 215 КПК).

Якщо говорити тільки про назву подібних способів отримання інформації, то заперечень не може бути. Дійсно, поняття негласні слідчі (розшукові) дії вперше зафіксовано в КПК України 2012 року. Водночас КПК УСРР 1922 р. передбачав таку слідчу дію, як виїмка поштово-телеграфної кореспонденції, яка могла здійснюватися тільки з дозволу прокурора (ст. 189) і проводилася в режимі, щоб про це не дізналися заінтересовані особи (негласно для них). Дальший розвиток процесуального регулювання негласних способів отримання інформації про обставини злочину спостерігаємо в КПК України 1960 р. Він містив нормативне регулювання таких слідчих дій, як «Накладення арешту на кореспонденцію і зняття інформації з каналів зв'язку» (ст. 187), «Огляд і виїмка кореспонденції та дослідження інформації, знятої $з$ каналів зв' язку» (ст. 187¹). Безсумнівно, що ці слідчі дії проводилися в спосіб, щоб про це не стало відомо особам, щодо яких їх застосовували та широкому колу осіб. Понятими для участі в слідчій дії залучали осіб із числа службовців цієї установи. Такий порядок проведення слідчих дій відповідає загальним положенням досудового розслідування - недопустимості розголошення відомостей досудового розслідування (ст. 222 КПК).

Дослідники цього питання зазначають, що інститут спеціальних процесуальних дій зародився в зарубіжних країнах наприкінці 80-х років минулого століття. Йдеться, зазначають вони, про легалізацію у кримінальному процесі дій і заходів, які, по суті, $\epsilon$ розвідувальними, таємними, створення на їх основі нових процесуальних форм, насамкінець нових слідчих дій зі збирання доказів [4, с. 107]. Зазначимо, по-перше, що специфічною особливістю усіх слідчих дій, а не тільки негласних, є їх пошуково-пізнавальна (іншими словами, розшукова) складова [11, с. 392], подруге, вони мають проводитися з додержанням вимоги про нерозголошення відомостей досудового розслідування (ст. 222 КПК).

Аналіз норм КПК ФРН дає змогу дійти висновку, що в ньому не передбачено окремого розділу, який був би присвячений негласним методам отримання інформації. Зокрема, восьмий розділ має назву «Виїмка, контроль над засобами зв' язку, растровий розшук, використання технічних засобів, використання «прихованих агентів» та обшук». В одному ряду 3 гласними методами отримання інформації містяться й ті, що застосовуються негласно. Так, у § 100 а врегульовано порядок контролю над засобами телекомунікації. На відміну від КПК України, у цій нормі наведено перелік злочинів, під час розслідування яких може застосовуватися цей захід. 
Розпорядження про контроль і запис із засобів телекомунікації (§100 а) має право віддати тільки суддя. У разі небезпеки зі зволіканням розпорядження може бути віддано й прокуратурою, але втратить силу, якщо воно не буде підтверджено суддею протягом трьох днів. Крім того, допускається застосування иे інших заходів без відома особи, інтересів якої вони стосуються. До них належить: фотографування і відеозапис; використання інших призначених для спостереження спеціальних технічних засобів для з'ясування обставин справи або для встановлення місця перебування злочинця у разі розслідування тяжкого злочину і коли з'ясування обставин справи або встановлення місця перебування злочинця іншим способом менш переспективно або може бути ускладнено (\$100 c). Також передбачається можливість отримання довідки про телекомунікаційні з'єднання щодо тяжких злочинів, перелік яких визначено в законі (§100 д).

Дещо інакше виглядає порядок процесуального врегулювання негласних засобів отримання інформації в КПК республік колишнього СРСР. Аналіз їх законодавства свідчить, що спеціальних розділів або глав, у яких зосереджено норми про порядок негласного отримання інформації не виділено, a ї кількість досить обмежена. Скажімо, у КПК Республіки Білорусь (глава 24) та РФ (глава 25) накладення арешту на поштовотелеграфні та інші відправлення, прослуховування і запис переговорів врегульовані поряд 3 обшуком та виїмкою, тобто розглядаються як традиційні слідчі дії.

У КПК Республіки Молдова розглядувані дії віднесено до засобів і методів доказування (глава 3). У цій главі виділена ч. 5 «Накладення арешту на поштову кореспонденцію та прослуховування переговорів», де зосереджено норми, якими регулюється процес накладення арешту на кореспонденцію (ст. 133), огляд і виїмка арештованої кореспонденції (ст. 134), прослуховування переговорів (ст. 135), провадження прослуховування, звукозапису переговорів та їх засвідчення (ст. 136), відеозапис та фотографування (ст. 137).

У недалекому минулому майже не можливо відшукати наукову працю щодо розкриття злочинів, у якій не було б рекомендацій щодо організації взаємодії між слідчими і оперативними підрозділами правоохоронних органів. Такі праці містили рекомендації щодо порядку обміну інформацією, передусім зібрану застосуванням оперативно-розшукових заходів, переважно негласного характеру, на різних етапах протидії злочинній діяльності.

Подібне ставлення до можливості і форм використання інформації, що отримана застосуванням оперативно-розшукових заходів певною мірою можна було вважати виправданим. На той час сторона захисту була суттєво обмежена в збиранні та поданні відомостей на користь свого підзахисного.

На сьогодні можливості захисту змінилися, а також стали суттєво розширеними у виявленні й поданні до суду джерел інформації на користь підзахисного. Крім того, зазначимо, що самостійність слідчого в прийнятті процесуальних рішень і проведенні слідчих дій на сучасному етапі державотворення суттєво обмежена. Не далеко той час, коли жодного 
рішення слідчий особисто не буде приймати без погодження з керівником слідчого підрозділу, прокурором або судом. Про яку небезпеку може йтися у зв' язку із розширенням інструментарію пізнавальної діяльності слідчого, яка відбуватиметься під прискіпливим прокурорським наглядом і судовим контролем?

Висновки. Запровадження інституту негласних слідчих (розшукових) дій є закономірним результатом розвитку кримінального процесуального законодавства, головна мета якого полягає в забезпеченні прав та інтересів обох сторін кримінального провадження. Пошуки сучасних ефективних засобів отримання інформації для розкриття злочинів з метою притягнення винних до відповідальності й поновлення порушених прав потерпілих будуть продовжуватись і надалі. Уже на сьогодні КПК доповнено ст. 269-1 «Моніторинг банківських рахунків», а також надано пропозиції щодо доповнення глави 16 КПК параграфом «Заходи забезпечення кримінального провадження у сфері інформаційних технологій», спрямовані на врівноваження можливостей сторін у досягненні істини, про що зазначається в ст. 31 Конституції України. Слідчий не може залишатися в гірших умовах, ніж сторона захисту, у забезпеченні засобами виявлення джерел інформації і подання ії для розгляду суду. Якщо сторона захисту може використовувати будь-які засоби для виявлення джерел інформації, крім злочинних, то слідчий може застосовувати лише ті засоби, що передбачені законом у визначеному ним порядку (дотримання процесуальної форми).

\section{Використані джерела:}

1. Солодков А. Забезпечення права на справедливий суд у кримінальному провадженні: окремі питання правозастосування. Право України. 2013. № 11. С. 55-62.

2. Дубинський А. Я. Вибрані праці. Киӥв : Центр учбової літератури, 2014. 430 с.

3. Погорецький М. А. Поняття, зміст та структура кримінального процесу: проблеми теорії та практики. Право України. 2013. №11. С. 42-54.

4. Ходанович В. О. Проведення негласних процесуальних дій за кримінальнопроцесуальним законодавством Німеччини, Швейцарії та Франції. Вісник Академії адвокатури України. Киӥв : ВЦ Академії адвокатури України, 2016. Т. 13. Число 3(37). C. 106-114.

5. Шумило М. Є. Поліційна і кримінально-процесуальна діяльність: на стику минулого і сучасного. Вісник Академії адвокатури України. Київ : Академія адвокатури України, 2015. Т. 12. Число 2(33). С. 223-234.

6. Шерудило В. О. Процесуальний порядок проведення негласних слідчих (розшукових) дій, пов'язаних із втручанням у приватне спілкування: автореф. дис. ... канд. юрид. наук : 12.00.09. Київ, 2018. 20 с.

7. Дубинский А. Я. Исполнение процессуальных решений следователя. Правовые и организационные проблемы. Київ : Наукова думка, 1984. 182 с.

8. Шумило М. Є. Оперативно-розшукові і слідчі дії: взаємозв'язок і розбіжність (гносеологічна і правова природа). Становлення системи негласного розслідування у кримінально-процесуальному законодавстві України : матеріали круглого столу (м. Київ, 07 жовтня, 2011 р.). Київ : ФОП Ліпкан О.С., 2011. С. 24-29.

9. Гольдберг Н. О. Гарантії забезпечення конституційних прав і свобод особи, що застосовуються при проведенні негласних слідчих (розшукових) дій. Актуальні 
питання реформування правової системи: зб. матеріалів XIII Міжнар. наук.-практ. конф. (Луцьк, 24-25 червня 2016 р.). Луцьк : Вежа-Друк, 2016. С. 252-254.

10. Антология сыска: от полиции к внешней разведке [В 14 т.]. Київ : Знания Украины, 2006. Т. 1 : Уголовный сыск : документы и материалы (XI-нач. XX ст.). 612 с.

11. Тіщенко В. В. Вибрані твори. Одеса: Видавничий дім «Гельветика», 2017. 436 с.

Стаття надійшла до редколегї 17.01.2019

Лукьянчиков Е. Д., доктор юридических наук, профессор, профессор кафедры информационного права и права интеллектуальной собственности Национального технического университета Украины «Киевский политехнический институт имени Игоря Сикорского» (г. Киев, Украина)

Лукьянчиков Б. Е., кандидат юридических наук, доцент, главный научный сотрудник института специальной подготовки Национальной академии Прокуратуры Украины (г. Киев, Украина)

\section{действий}

Формирование института негласных следственных (розыскных)

Статья посвящена анализу нормативного регулирования инструментария познавательной деятельности по расследованию преступлений. Рассмотрены взгляды ученых по определению следственных действий и отграничения их от других процессуальных действий и средств обеспечения уголовного производства. Раскрыто объективные предпосылки закрепления в УПК Украины ряда следственных (розыскных) действий, сведения о факте и методы проведения которых не подлежат разглашению.

Сделан вывод о том, что введение института негласных следственных (розыскных) действий является закономерным результатом развития уголовного процессуального законодательства, главная цель которого заключается в обеспечении прав и интересов обеих сторон уголовного производства.

Ключевые слова: преступление, средства познавательной деятельности, следственные (розыскные) действия, процессуальные действия, поиск, розыск, розыскная деятельность.

Lukianchykov Ie., Lukianchykov B. Creation of the Institute of the Secret Investigative (Search) Activities

The article is devoted to the analysis of the regulatory of the cognitive tools concerning the criminal investigation. It is examined the scientists' opinions about the definition of the investigative actions and the dissociation from the other proceedings and the means of the criminal proceedings. It is exposed the objective preconditions to ensure some investigative (search) actions, the information about the facts and the methods of investigation not be divulged by the Code of Criminal Procedure.

The purpose of article is to find out the covert investigative (search) activities, to define their place in the law of evidence, to search the procedure to found the evidence and to ensure it on the different stages of the establishing laws which regulate the legal relationship in the criminal procedure.

The main conclusions are the next: our country is on the way to the European integration which need from the public authorities the reliable and effective ensuring of the rights, the freedoms and the legitimate interests of citizens. It is clear that the public authorities whose the mission is to combat crimes must have the modern and reliable ways of getting information about it. Considering that this activity implies interference in the rights and private interests of citizens involved in the criminal 
procedure relationship, the law enforcement should be regulated by the provisions of the law. That explains the long work on the new Code of Criminal Procedure of Ukraine. The scientists try to establish and propose the provisions which could consider the rights and freedoms of not only victim but also suspected in a crime. Bearing in mind the nature of modern criminality and the personal qualities of criminals the legislation significantly expands the cognitive activity means. The Code of Criminal Procedure is completed by the chapter 21 whose the provisions define the mode to make the covert investigative (search) activities.

The investigative actions are one of the well-established institute of the criminal procedure. They are a part of the procedure actions that have the search, cognitive approach and provide the law of evidence. Their definition is the actions provided by criminal procedure law whose the approach is to obtain and check the getting evidences in the criminal procedure. They are provided by the investigator or the person conducting inquiry (in the cases provided by law - by the prosecutor and the chief of the investigators service) on the stage of pre-trial investigation according to the procedure requirements that have the cognitive approach.

The establishment of the covert investigative (search) activity institute is the natural result of the criminal procedure law development whose the goal is to guarantee the rights and the interests of two parts of criminal procedure. The search of the modern ways of getting information necessary to solve a crime and to bring perpetrators to justice and to restore the rights of victims will continue in the future. The scientists' proposals concerning the improvement of the getting information means for the criminal procedure are aimed to balance the opportunities of parts to achieve the true objective that the article 31 of Ukrainian law says. The investigator must have the effective cognitive activity means to provide the reliable information support for the adversarial proceedings. He can't be in worse conditions than the defense in the laws of evidence. If the defense can use any means to get the information source but not the criminal means, the investigator can use only the means provided by law (to respect the procedural law).

Key words: crime, means of cognitive activity, investigative (search) activities, proceedings, search, retrieval, investigative actions.

Маличева Н.P. доктор юридичних наук, професор, академік НАПрН України, завідувач відділу проблем аграрного, земельного, екологічного та космічного права Інституту держави і права імені В. М. Корецького НАН України (м. Київ, Україна)

Гурова A.M. кандидат юридичних наук, науковий співробітник відділу проблем аграрного, земельного, екологічного та космічного права Інституту держави і права імені В. М. Корецзького НАН України (м. Київ, Украӥна)

\section{ЗАРУБІЖНИЙ ДОСВІД ДЕРЖАВНО-ПРИВАТНОГО ПАРТНЕРСТВА ТА МОЖЛИВОСТІ ЙОГО ВПРОВАДЖЕННЯ В КОСМІЧНІЙ ГАЛУЗІ УКРАЇНИ}

У статті проведено огляд програмних документів космічного та господарського законодавств країн Європи, США, а також права Європейського 